\title{
50 Years of Lassa Fever Research
}

\author{
Robert F. Garry
}

\section{Contents}

1 Introduction

2 Overview of the Lassa Literature.

3 Lassa Fever Research by Decade.

3.1 The $1970 \mathrm{~s}$

3.2 The $1980 \mathrm{~s}$

3.3 The $1990 \mathrm{~s}$

3.4 The $2000 \mathrm{~s}$

3.5 The $2010 \mathrm{~s}$

4 Summary

References

\begin{abstract}
Lassa fever was first described as a clinical entity fifty years ago. The causative agent Lassa virus was isolated from these first known cases. This chapter reviews the key publications on Lassa fever research that appeared in the scientific literature at that time and over the ensuing decades.
\end{abstract}

\author{
R. F. Garry \\ Department of Microbiology and Immunology, Tulane University School of Medicine, \\ 1430 Tulane Avenue, New Orleans, LA 70118, USA \\ R. F. Garry $(\bowtie)$ \\ Zalgen Labs, LLC, 20271 Goldenrod Lane, Suite 2083, Germantown, MD 20876, USA \\ e-mail: rfgarry@tulane.edu \\ Current Topics in Microbiology and Immunology \\ https://doi.org/10.1007/82_2020_214 \\ (C) Springer Nature Switzerland AG 2020
}




\section{Introduction}

50 years ago as of this writing Lassa virus (LASV) was discovered and shown to be the causative agent of Lassa fever (Buckley et al. 1970; Frame et al. 1970; Pinneo and Pinneo 1971) Lassa fever is endemic in the countries of Nigeria, Sierra Leone, Guinea, and Liberia. Sporadic cases have been reported in other West African countries, with recent outbreaks in Togo and Benin (Shaffer et al. 2014; Andersen et al. 2015; WHO 2017; Manning et al. 2015; ECDC 2016) LASV isolates display high genetic diversity (Andersen et al. 2015; Bowen et al. 2000), with an expanding number of lineages and sub-lineages (Manning et al. 2015; Ehichioya et al. 2019; Whitmer et al. 2018). The main reservoir of LASV is Mastomys natalensis, a peridomestic rodent that is abundant across a wide range in sub-Saharan Africa (Monath et al. 1974b). LASV is transmitted vertically to the offspring of infected rodents and horizontally to humans via urine or feces or during the preparation of the rodent for food. Additional rodent reservoirs or intermediate hosts have been described and may vary by lineage (Olayemi et al. 2016b; Yadouleton 2019). Currently, the only available treatment is off-label use of the nucleoside drug ribavirin (Eberhardt et al. 2019). Progress has been made toward the development of an immunotherapeutic (Mire et al. 2017; Cross et al. 2016b) and a small molecule drug (Madu et al. 2018). While there is no approved Lassa fever vaccine, there are new initiatives to address this urgent public health need (Burki 2017). This chapter will review the presentation of Lassa fever research in the scientific literature.

\section{Overview of the Lassa Literature}

A PubMed search for "Lassa" on August 18, 2019, returned 1438 entries mentioning the virus or disease. By comparison "Ebola" returned 8458 entries, while "HIV" returned 350,652. A search for "cancer" returned almost 4 million entries $(3,914,091)$. During the 1970 s, the decade in which Lassa fever was first formally described there were 178 publications on Lassa fever or Lassa virus (Fig. 1). There were 220 Lassa publications in the 1980s, most from dedicated investigators with the US Centers for Disease Prevention and Control (CDC), the Army Medical Research Institute for Infectious Diseases (USAMRIID), the Special Pathogens Reference Laboratory at Porton Down in the UK, the Byelorussian Research Institute of Epidemiology and Microbiology in the Union of Soviet Socialist Republics (USSR) or the University of Ibadan, Nigeria. The civil conflict in West Africa as well as a general reduction in support for biomedical research leads to a drop off to only 119 articles published during the 1990s. However, spurred by the surge in funding for work on biothreat agents as a result of the anthrax letters sent after the 9/11 attack, the numbers of Lassa publications grew to 258 in the first decade of the new millennium. The inadequate response to the Ebola outbreak of 2013-16 prompted an acceleration of research on all emerging viruses (Ryschon 
Fig. 1 Number of Lassa fever publications in the scientific literature by decade

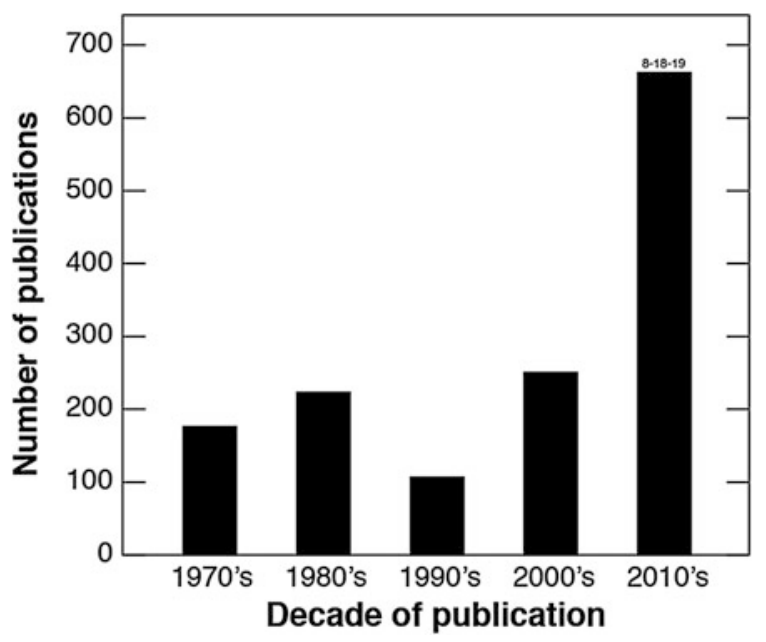

2014). 663 articles on Lassa have been published through mid-August 2019 with more to come before the end of the decade. There have been advances in understanding the virology, ecology, molecular biology, immunology, and genomics of LASV and progress toward countermeasures including diagnostics, therapeutics, and vaccines, which we summarize below.

The widespread distribution of LASV across West Africa coupled with evidence of natural selection for LASV resistance in humans suggests that Lassa fever might be an ancient human disease (Andersen et al. 2015; Sabeti et al. 2006). Molecular dating determined that current LASV variants originated in modern-day Nigeria approximately a thousand years ago and spread to countries to the west within the last several hundred years (Andersen et al. 2015). We estimated that the time to the most common recent ancestor (tMRCA) of sampled LASV strains to be 1057 years ago for the L segment and 650 years ago for the $S$ segment (Andersen et al. 2015). In contrast, LASV isolates in Sierra Leone have an estimated tMRCA of 150 years. A recent phylogeographic analysis of Liberian LASV genomes estimates a tMRCA of 300-350 years (Wiley et al. 2019). The scientific literature, however, contains little evidence for human infections prior to the discovery of LASV in 1969. Two missionaries were shown retrospectively to have a serological response to LASV after experiencing a febrile illness in 1952 while working in Nigeria (Fig. 2) (Bond et al. 2013). A likely outbreak of Lassa fever occurred in 1955 at Nixon Memorial Hospital in Segbwema, Sierra Leone (Fig. 2) (Rose 1956). It seems unlikely that LASV, which does not spread effectively in humans, abruptly acquired the ability to cause human disease. These retrospective examples were probably not the only human cases of Lassa fever in West Africa prior to the formal description of the disease. It is difficult to distinguish common febrile illnesses, such as malaria, typhoid fever, leptospirosis, and arbovirus diseases, from Lassa fever on the basis of clinical presentation alone. Sporadic outbreaks with high morbidity and mortality 


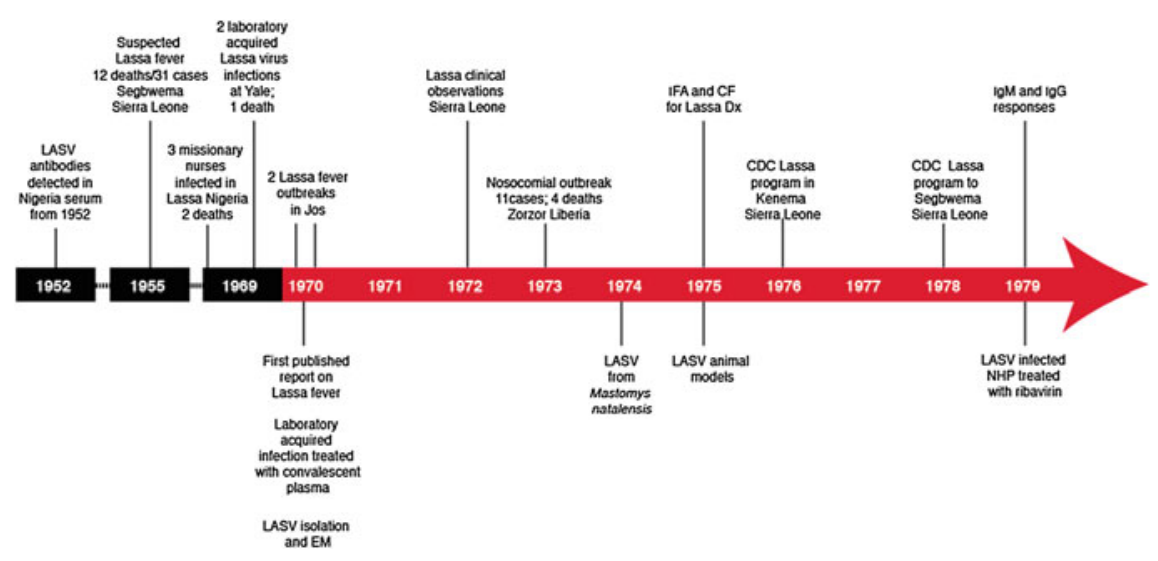

Fig. 2 Key events and scientific publications regarding Lassa fever prior to and during the 1970s

are likely to have occurred. Anecdotally, there are accounts of deaths due to what was likely Lassa fever in people living in Kenema District and surrounding areas going back to at least the 1940s (Dr. Donald S. Grant, personal communication).

\section{Lassa Fever Research by Decade}

\subsection{The 1970s}

Lassa fever was first described in 1969 (Fig. 2) (Frame et al. 1970; Buckley and Casals 1970; Speir et al. 1970). The first known patient was a Serving In Mission (SIM) nurse, who was infected while working in a hospital near Lassa, Nigeria (Pinneo and Pinneo 1971). She was transported to Bingham Hospital in the city of Jos some 300 miles away, where she died. Two other Bingham missionary nurses were infected while caring for their colleague and died. A third Bingham nurse, Lily (Penny) Pinneo was also infected, but survived after being transported to New York City (Watts 2013). Blood samples from the infected nurses were shipped to the Yale Arbovirus Research Unit (YARU) where the first Lassa laboratory research was initiated. In June 1969, two YARU researchers were infected with LASV, one fatally (Leifer et al. 1970). Dr. Jordi Casals, an eminent virologist, received blood donated from Pinneo as passive immunotherapy (Leifer et al. 1970). LASV, a novel arenavirus, was isolated from the blood of the missionary nurses and Casals (Buckley et al. 1970; Buckley and Casals 1970). The isolate from Pinneo was designed as the type strain.

In early 1970, two hospitals in Jos, Nigeria, experienced nosocomial outbreaks of Lassa fever, including Bingham Hospital (Troup et al. 1970; Carey 1972). There were 28 hospital-acquired cases with 13 deaths (46\% case fatality rate, CFR) 
(Troup et al. 1970; White 1972). The outbreak was investigated by a team from the Rockefeller Foundation Virus Research Laboratory in Ibadan, Nigeria, led by Dr. Don Carey who described the epidemiology, clinical features, and pathology of the disease (Troup et al. 1970; Carey 1972; Henderson et al. 1972). Dr. Jeanette Troup was tragically infected while performing an autopsy of one of the 1970 Jos cases and died from Lassa fever.

In March 1972, Dr. Thomas P. Monath a CDC research fellow at the Rockefeller laboratory in Ibadan, Nigeria, was called to investigate a Lassa fever outbreak in Zorzor, Liberia (Monath et al. 1973). Monath, who participated in an important segment of the early work in Sierra Leone, has recently written an historical review of the first 10-15 years after discovery, which is highly recommended (Monath 2019). Monath recounts how he was joined in Liberia by Nurse Pinneo, who was immune to LASV infection (Bond et al. 2013) and performed many of the high-risk procedures. As in Jos, most of the 11 cases (4 deaths, 36\%) were on a single ward, in this instance the obstetrics ward. Shortly after the outbreak in Zorzor, CDC was alerted to an outbreak in Panguma, a village in the Eastern Province of Sierra Leone (Monath et al. 1974a; Fraser et al. 1974). The Panguma outbreak was different than previous outbreaks that were driven by nosocomial infections. The 63 likely cases in and around Panguma were community-acquired and had occurred over two years. It was during the investigation of these cases that Monath identified the rodent host of LASV, the multimammate mouse Mastomys natalensis (Monath et al. 1974b).

In 1976, the Sierra Leone Ministry of Health and Sanitation (MoHS) and CDC established Lassa fever treatment wards and research facilities in the Eastern Province (Khan et al. 2008). Three centers at Panguma, Segbwema, and Kenema became major sites for Lassa fever research throughout the 1970s and 1980s (McCormick and Fisher-Hoch 1996). The CDC Lassa Fever Project was initially headquartered in Kenema, under the leadership of Dr. Joseph McCormick and moved to Segbwema in 1978 when Dr. Patricia Webb became Director (Chu 2018). The 1970s were marked by the development of the first Lassa fever diagnostics (Frame et al. 1979) including complement fixation and immunofluorescence assays. (Fabiyi and Tomori 1975; Arnold and Gary 1977; Wulff and Johnson 1979) Later in the decade, the first animal models were described (Kiley et al. 1979; Stephen and Jahrling 1979) and there was the first demonstration in nonhuman primates (NHPs) that ribavirin might be a treatment option for Lassa fever (Stephen and Jahrling 1979).

Dr. Oyewale Tomori, then with the University of Ibadan in Nigeria, has made numerous contributions to Lassa fever research (Tomori et al. 1987, 1988, 1999; Tomori and Fabiyi 1979; Smith et al. 1979; Fabiyi et al. 1979) This includes the important observation in 1979, since confirmed in numerous populations, that many Nigerians have hemorrhagic fever antibodies in Nigerian populations (Fabiyi et al. 1979). Tomori, who is the Head of the Nigerian National Academy of Sciences, is still impacting Lassa fever research today while demanding excellence in research with grace and wit. 


\subsection{The 1980s}

The 1980s are notable for the contributions of several extraordinary teams working on both sides of the Atlantic (Fig. 3). The team from CDC, including Drs. Joseph McCormick, Susan Fisher-Hoch, Patricia Webb, Karl Johnson, and others made numerous contributions on clinical, pathologic, virologic, epidemiologic, and therapeutic aspects of Lassa fever (Walker et al. 1982b; Trappier et al. 1993; McCormick et al. 1992; McCormick 1986). They described effective therapy with oral and intravenous ribavirin (McCormick et al. 1986), the importance of Lassa fever in children (Webb et al. 1986), and a plasma inhibitor of platelet aggregation in Lassa fever patients (Roberts et al. 1989; Cummins et al. 1989). The CDC team also performed a case-control study of Mastomys natalensis and humans in Lassa virus-infected households in Sierra Leone (Keenlyside et al. 1983) and a prospective study of maternal and fetal outcome in acute Lassa fever infection during pregnancy (Price et al. 1988). Aspartate transaminase levels less than $150 \mathrm{IU} / \mathrm{L}$ were shown to be a prognostic indicator of fatal Lassa fever (McCormick et al. 1987a; Johnson et al. 1987). McCormick and colleagues also confirmed that inapparent LASV infections occurred (McCormick et al. 1987b) and placed a focus on improving patient care and prevention (Fisher-Hoch et al. 1995; Fisher-Hoch et al. 1985). The CDC group developed NHP models of Lassa fever (Fisher-Hoch et al. 1987) and studied platelet function and fibrinogen in LASV-infected monkeys (Walker et al. 1982a; Lange et al. 1985).

Dr. Peter B. Jahrling and his team, who were based at United States Army Medical Research Institute of Infectious Diseases (USAMRIID), developed animal models of Lassa fever, including infections of guinea pigs, rhesus macaques, and cynomolgus macaques. Harkening back to the treatment afforded Casels, Jahrling with Dr. Clarence J. (CJ) Peters, investigated passive antibody alone and in combination with ribavirin as treatments for Lassa fever (Frame et al. 1984). In NHPs, they showed that strain-specific neutralizing antibody was important for the success

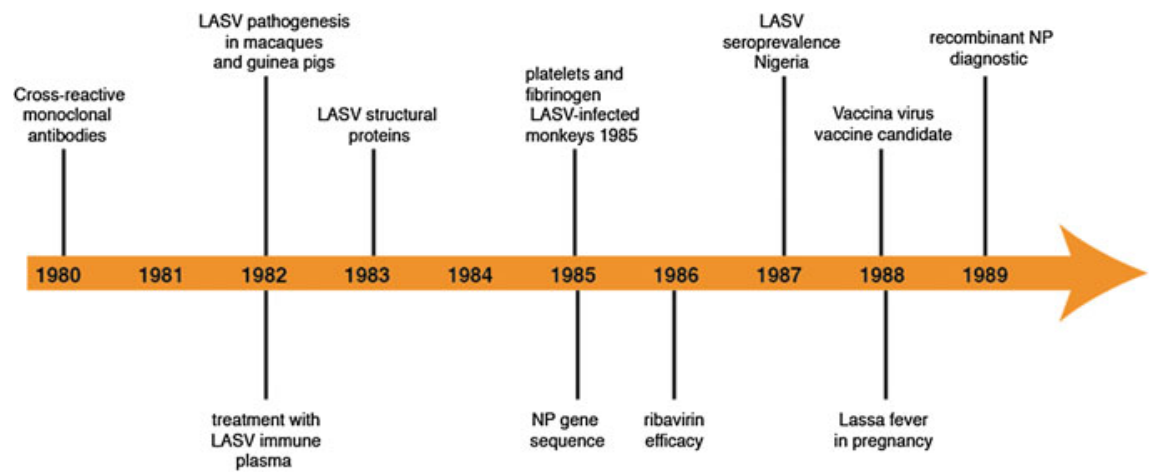

Fig. 3 Key events and scientific publications regarding Lassa fever during the 1980s 
of passive antibody therapy. With John Frame of SIM and Division of Tropical Medicine, School of Public Health, College of Physicians and Surgeons, Columbia University, Jahrling also conducted a number of clinical and virological studies of Lassa fever in Liberia. Jahrling was the first Director of the National Institutes of Health (NIH) Integrated Research Facility (IRF), which like USAMRIID is on the campus of Fort Detrick (Jahrling et al. 2014).

The 1980s are also notable for contributions in the area of LASV molecular biology of Dr. J. Christopher S. Clegg and colleagues from the Special Pathogens Reference Laboratory at Porton Down in the UK. Clegg and his team described the structural proteins of LASV and sequenced and expressed the nucleocapsid gene (Clegg et al. 1986; Clegg and Lloyd 1983). They were the first to demonstrate that Lassa fever could be diagnosed using recombinant nucleocapsid antigen (Lukashevich et al. 1993; Barber et al. 1990; Lloyd et al. 1989). The team also constructed a vaccinia virus recombinant expressing LASV nucleocapsid protein and demonstrated protection against fatal Lassa fever in guinea pigs (Clegg and Lloyd 1987). A similar construct and results were reported by the CDC group, who also tested vaccinia recombinants expressing LASV glycoprotein (Morrison et al. 1989; Fisher-Hoch et al. 1989; Auperin et al. 1988).

Dr. Igor Lukashevich, now at the University of Louisville, has also sustained excellence in Lassa fever research over many decades. In the 1980s, while working at the Byelorussian Research Institute of Epidemiology and Microbiology in the United Soviet Socialist Republic (USSR) Lukashevich studied the replication of LASV in cell culture (Lukashevich et al. 1982, 1983, 1999) documented inhibition of arenavirus reproduction in cell cultures by ribavirin (Petkevich et al. 1981), demonstrated LASV lethality for inbred mice (Lukashevich 1985) and characterized LASV monoclonal antibodies. Many of Dr. Lukashevich's early studies were published in Russian. Other significance Lassa research of the 1980s includes the observation by Dr. Michael J. Buchmeier that monoclonal antibodies to lymphocytic choriomeningitis virus (LCMV) react with LASV and other pathogenic arenaviruses (Buchmeier et al. 1981; Buchmeier et al. 1980).

\subsection{The 1990s}

Several international programs continued Lassa fever research into the 1990s (Fig. 4). Sensorineural deafness was confirmed as a common sequelae of Lassa fever (Rybak 1990; Cummins et al. 1990; Cummins 1992) and the use of polymerase chain reaction (PCR) for Lassa fever diagnosis was explored (Trappier et al. 1993; Lunkenheimer et al. 1990). However, momentum for Lassa fever research was blunted by a violent civil conflict sometimes referred to as the Blood Diamonds 
War that started in 1991 and continued until 2002. ${ }^{1}$ The West African conflict cost at least 50,000 lives with local people suffering killings, mutilation, and other atrocities, mainly due to brutal warfare waged by rebel group, the Revolutionary United Front (RUF) (Campbell 2002). RUF occupied the diamond mining regions in the Lassa fever endemic regions in Eastern Sierra Leone to get access to diamonds that they traded for arms and funding to support their actions. The violence forced suspension of CDC involvement in Sierra Leone. However, admission to the Kenema Government Hospital (KGH) Lassa ward, led by Dr. Aniru Conteh, a Sierra Leonean physician continued throughout the civil conflict (Wright 2004). Lassa research continued elsewhere albeit at a slower pace. Sequencing studies were performed on the LASV L gene by Lukashevich and an international team (Lukashevich et al. 1997), and Lassa fever became further established as a significant imported tropical virus infection (Schmitz et al. 1996; Johnson and Monath 1990).

\subsection{The 2000s}

While their Lassa program in Sierra Leone was shut down during the Blood Diamonds War, CDC deployed Drs. Austin H. Demby and Daniel G. Bausch to neighboring Guinea. Data were collected intermittently between early 1996 and late 1999. Several significant publications from this work in Guinea appeared in the 2000s, including an investigation of the epidemiology of Lassa fever (Bausch 2001), and the distribution and prevalence of LASV in small mammals (Fig. 5) (Demby 2001). Demby, Bausch, and colleagues also performed an important comparison of enzyme-linked immunosorbent assays (ELISA), indirect fluorescent-antibody test (IFA), and virus isolation for diagnosis (Bausch et al. 2000).

The 2000s featured numerous breakthroughs that were critical for understanding Lassa virology (Fig. 5). Drs. Michael Bowen, Stuart Nichol, and others at CDC published a landmark paper on the genetic diversity of LASV (Bowen et al. 2000). Dr. William R. Gallaher published a seminal paper confirming that viral fusion proteins fit a limited number of structural scaffold and suggested the possibility that arenavirus and filovirus glycoproteins are diverged from a common ancestor (Gallaher et al. 2001). Dr. Michael B. A. Oldstone lead the group that discovered that $\alpha$-dystroglycan is the receptor for Old World arenaviruses including LASV, as well as some New World arenaviruses (Spiropoulou et al. 2002; Smelt et al. 2001; Kunz et al. 2001, 2003, 2004a, b, 2005; Cao et al. 1998) Oldstone's essential work is under-represented in this review because he focused much of his work on LCMV, the prototypic arenavirus (Kunz et al. 2004a; Cao et al. 1998; Oldstone and Dixon 1970; Whitton et al. 1988; Welsh and Oldstone 1977; Welsh et al. 1977;

\footnotetext{
${ }^{1}$ After the "blood diamond" conflict: Lassa fever in Sierra Leone. Clin Infect Dis 59:iii-iv (2014).
} 


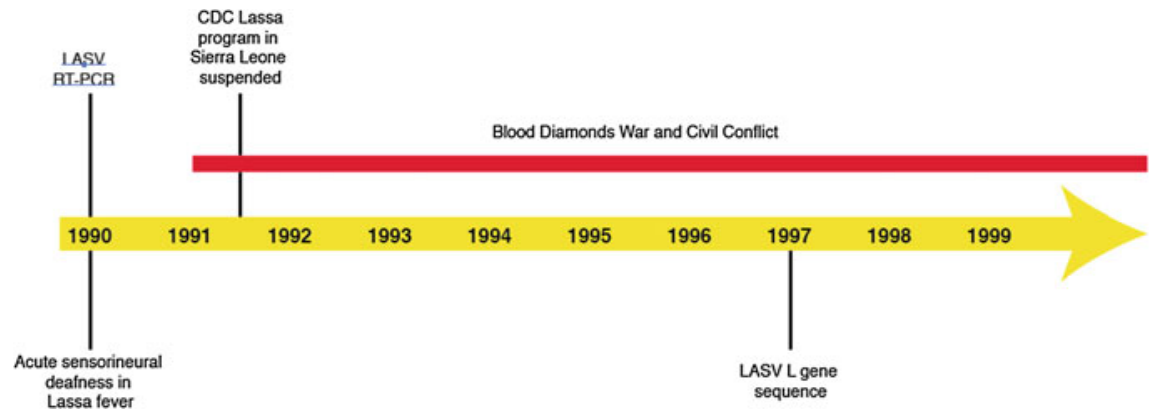

Fig. 4 Key events and scientific publications regarding Lassa fever during the 1990s

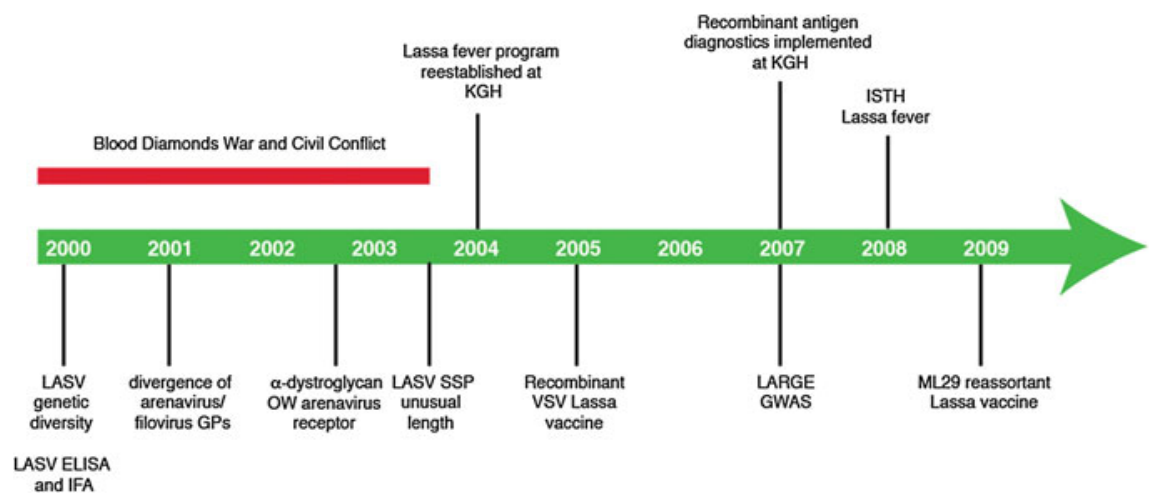

Fig. 5 Key events and scientific publications regarding Lassa fever during the 1920s

Valsamakis et al. 1986; Tishon et al. 1993, 1988; Teng et al. 1996; Sullivan et al. 2011; Southern et al. 1987; Salvato et al. 1991; Riviere et al. 1985, 1986; Oldstone et al. 1973, 1985, 1990; Oldstone and Dixon 1972; Oldstone et al. 1980; Lee et al. 2000; Klavinskis and Oldstone 1989; Ahmed et al. 1984) It was also shown that the signal peptide of the LASV glycoprotein exhibits an unusual length (Eichler et al. 2003). An additional development of note in the 2000s includes the demonstration in NHPs of the safety, immunogenicity, and efficacy of a Mopeia virus-based Lassa reassortant vaccine ML29 (Lukashevich et al. 2008).

Work in the 2000s also identified that role the zinc protein $(\mathrm{Z})$ in arenavirus budding (Strecker et al. 2003). Curiously, newly described arenaviruses, the hartmaniviruses in snakes and the antennaviruses of fish, do not encode a $\mathrm{Z}$ protein (Garry and Garry 2019). These studies on $Z$ have been complimented by work done on New World arenaviruses by Dr. Jack H. Nunberg and team on Junin virus (JUNV) (York and Nunberg 2007). The work of Nunberg and his collaborators on the stable signal peptide of JUNV, entry and entry inhibitors have been major contributions to knowledge about arenaviruses (York et al. 2004, 2008, 2010; York 
and Nunberg 2006, 2018) Other key studies of New World arenaviruses include, but are not limited to, development of a successful JUNV vaccine (Candid-1) and convalescent plasma as a treatment for JUNV infection by Dr. Delia Enria (Enria and Maiztegui 1994; Enria et al. 2008; Enria and Barrera Oro 2002; Enria et al. 2010) and structural studies on Machupo virus glycoprotein by Dr. Stephen C. Harrison (Mahmutovic et al. 2015; Abraham et al. 2010).

In 2007, Dr. Pardis C. Sabeti and colleagues at Harvard University and the Broad Institute of Harvard and MIT used long-range haplotype methods to identify human alleles that have undergone recent selection (Sabeti et al. 2007). Two populations in Nigeria exhibited signatures of selection in the gene for the LARGE protein, a glycosylase that post-translationally modifies $\alpha$-dystroglycan, the cellular receptor for LASV. DMD, which encodes a cytosolic adaptor protein that binds to $\alpha$-dystroglycan and is critical for its function, also appears to be under selection.

Following the cessation of hostilities in the West African civil conflict, a consortium of Lassa fever researchers, in close collaboration with the Sierra Leone MoHS, began rebuilding the clinical and laboratory infrastructure at KGH beginning in 2003 (Khan et al. 2008). Tragically, Dr. Conteh contracted Lassa fever and died of the Lassa fever in 2004 (Wright 2004). A then-recent graduate from the medical school in Freetown, Dr. Sheik Humarr Khan became the new director of the KGH Lassa fever program (Khan et al. 2008). The first priority for Lassa research at $\mathrm{KGH}$ was the development of improved diagnostic assays. Dr. Luis M. Branco, now at Zalgen Labs, developed bacterial-based systems for expression and purification of recombinant LASV proteins of immunological relevance (Branco et al. 2008). The 2000s also saw the establishment of a partnership between Sabeti's group and investigators at the Irrua Specialist Teaching Hospital (ISTH), which houses Nigeria's leading clinical and laboratory Lassa research center (Sullivan et al. 2020; Siddle et al. 2018; Okokhere et al. 2018; Okogbenin 2019; Akhuemokhan et al. 2017; Ajogbasile et al. 2020) An additional partnership at ISTH included Dr. Stephan Günther's group at the Bernhard Nocht Institute (BNI) of Tropical Medicine in Hamburg Germany (Vieth et al. 2004; Schmitz et al. 2002; Omilabu et al. 2005) Dr. Elizabeth Fichet-Calvet, who is now with the BNI group, began her important investigations on Mastomys and other LASV rodent hosts in the 2000s (Lecompte et al. 2006; Kerneis et al. 2009; Fichet-Calvet et al. 2007; Fichet-Calvet et al. 2008).

\subsection{The 2010s}

Lassa fever research on the decade of the 2010s was impacted by the largest outbreak of Ebola to date in the Lassa fever zone of West Africa (Fig. 6) (Hartnett et al. 2015). The West African Ebola outbreak was officially declared on March 23, 2014. Augustine Goba, director of the KGH Lassa laboratory, diagnosed the first 


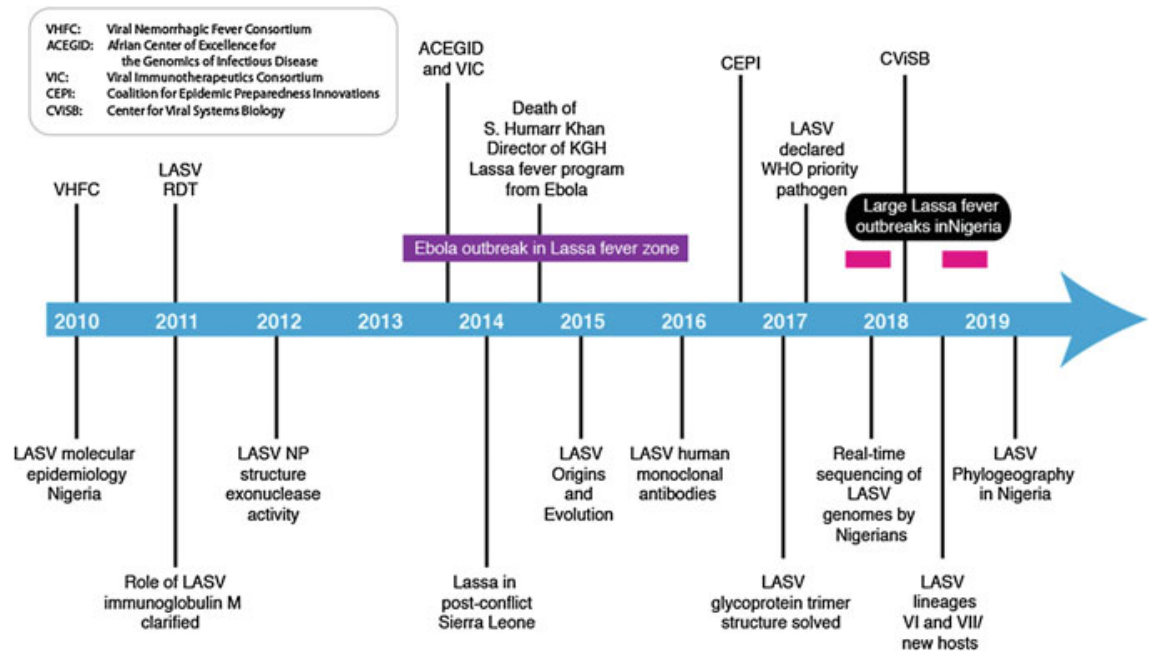

Fig. 6 Key events and scientific publications regarding Lassa fever during the 1980s

documented Ebola in Sierra Leone on May 25, 2014 (Goba et al. 2016). The majority of subsequent Ebola cases in West Africa can be traced back to a single transmission chain that includes this case (Gire et al. 2014). Thereafter, KGH received and cared for numbers of Ebola patients that quickly overwhelmed the capacity for safe management. Dr. Khan and head nurse Mbalu Fonnie were among numerous healthcare workers at $\mathrm{KGH}$ that contracted Ebola while administering care to infected patients and lost their lives (Bausch et al. 2014). A total of 28,616 Ebola cases with 11,310 deaths were reported in Guinea, Liberia, and Sierra Leone (Hartnett et al. 2015). An additional 36 cases and 15 deaths occurred in other countries (Hartnett et al. 2015).

The Viral Hemorrhagic Fever Consortium (VHFC), a partnership of international research institutions investigating Lassa, Ebola, and other biothreat viruses, was established in 2010. The VHFC compiled and analyzed the most complete sets of clinical and laboratory data available at the time for Lassa fever (Shaffer et al. 2014) as well as Ebola (Schieffelin et al. 2014). Recombinant antigen immunoassays for the diagnosis of Lassa fever (Boisen et al. 2018) and Ebola (Cross et al. 2016a; Boisen et al. 2016) were also developed. Sabeti and her team from Harvard/ Broad developed a robust RNA-seq method for generating complete de novo assemblies of LASV and EBOV genomes in clinical and biological samples (Matranga et al. 2014). While in Sabeti's lab Dr. Kristian G. Andersen, now at Scripps Research, elucidated the spread of LASV across West Africa by genomic sequencing (Andersen et al. 2015). This migration was accompanied by changes in LASV genome abundance, fatality rates, codon adaptation, and translational efficiency. Later, Andersen founded the Center for Viral Systems Biology (CViSB; pronounced "SEE-VIZ-bee"). The mission of CViSB is to identify factors that 
determine outcomes from viral infections and elucidate the molecular and immunological networks that determine outcomes of human disease. Dr. Christian T. Happi of Redeemer's University established the Africa Center of Excellence for the Genomics of Infectious Diseases (ACEGID) in 2014 with support from the World Bank and NIH. ACEGID is located at the Redeemers University in Ede, Nigeria and is building the first state-of-the-art genomics laboratory on the African continent. ACEGID was well poised to respond to the protracted large Lassa fever outbreaks that occurred in Nigeria in 2018 and 2019 (Siddle 2018).

Dr. James E. Robinson of Tulane University and the VHFC team produced and characterized the first set $(>120)$ of human monoclonal antibodies (huMAbs) to LASV (Robinson et al. 2016). A comprehensive epitope map of the Lassa virus glycoproteins was derived, including mapping the location of the major neutralizing, non-neutralizing, and linear epitopes. Drs. Thomas W. Geisbert, Chad E. Mire, and Robert W. Cross of the University of Texas Medical Branch (UTMB) in Galveston examined the ability of these antibodies to protect against fatal Lassa fever in guinea pig and nonhuman primate models (Mire et al. 2017; Cross et al. 2016a, b). The UTMB team showed that a cocktail of three LASV huMAbs each directed to a distinct epitope on GPC could reverse late symptomatic Lassa fever in cynomolgus macaques even with delaying treatment for more than a week post-infection (Hastie et al. 2019).

Drs. Erica Ollmann Saphire and Kathryn M. Hastie, formerly of Scripps Research and both now at the La Jolla Institute of Immunology, provided X-ray crystallographic structures of the major structural proteins of members of the arenavirus family. They solved the structure of LASV NP revealing an unexpected exonuclease activity (Hastie et al. 2011a, b, 2012a, b) and the first complete prefusion structure of the LASV glycoprotein complex (GPC) in complex with a huMAb (Hastie et al. 2017, 2019; Hastie and Saphire 2018). In 2014, Saphire established the Viral Hemorrhagic Fever Immunotherapeutic Consortium, or VIC, to develop antibody therapeutics against emerging viruses. The VIC represents a fieldwide collaboration of laboratories from around the world united to understand features that lead to antibody-mediated protection and ideal treatments for viral infections.

VHFC investigators were not of course the only Lassa researchers to make important contributions in the 2010s. Information has accumulated that LASV lineages and sub-lineages (clades) cluster geographically (Bowen et al. 2000; Siddle et al. 2018; Kafetzopoulou et al. 2019). The initial isolate of LASV (Pinneo) representing lineage I (LI) has rarely been observed in recent samplings (Ehichioya et al. 2019; Siddle et al. 2018; Olayemi et al. 2016a). LII and LIII are the most common lineages in Nigeria and are found in the southern and central regions, respectively (Ehichioya et al. 2011; Oloniniyi et al. 2018). LIV LASV is present in Sierra Leone, Liberia, and Guinea (Andersen et al. 2015; Wiley et al. 2019). LASV LV is found in Mali and Ivory Coast (Manning et al. 2015; Safronetz et al. 2013). LASV isolates from a Hylomyscus pamfi rodent trapped in Nigeria (Olayemi et al. 2016b) and from a nosocomial outbreak in Togo (Whitmer et al. 2018) have 
been proposed to represent new LASV Lineages LVI and LVII, respectively. Drs. Connie S. Schmaljohn and Katherine A. Cashman of USAMRIID showed that DNA vaccine delivered by dermal electroporation fully protects cynomolgus macaques against Lassa fever (Jiang et al. 2019; Cashman et al. 2017a, b) They also presented evidence that immune-mediated systemic vasculitis is the cause of sensorineural hearing loss in LASV-infected cynomolgus macaques (Cashman 2018). Dr. Schmaljohn recently became Director of the IRF.

Other significant advancements were that the World Health Organization declared LASV a priority pathogen (Mehand et al. 2018). The US CDC and Biomedical Advanced Research and Development Authority (BARDA) should follow suit and designate LASV, and other arenaviruses that cause hemorrhagic fevers as a Tier 1 agents. Pathogenic coronaviruses and paramyxoviruses should also be designated as Tier 1 agents. Another highly significant development was that founding of the Coalition for Epidemic Preparedness Innovations (CEPI), which has prioritized the accelerated development of a Lassa fever vaccine (Bernasconi et al. 2020; Gouglas et al. 2019). CEPI has also initiated an epidemiological study in five West African countries as part of their strategy to facilitate vaccine development efforts. ${ }^{2}$

\section{Summary}

The scientific literature on Lassa fever continues to expand in support of the more intense efforts against this important public health threat. Already in the decade of the 2020s near-atomic resolution structures of Lassa and Machupo virus RNA polymerases were reported (Peng et al. 2020). These structures display a similar overall architecture to polymerases of other RNA viruses, but including an arenavirus-specific domain that regulates the polymerase activity. New insights into the role of T-cell immunity against LASV have also been obtained (Sullivan et al. 2020). The next decade of research will produce important advances in the control and treatment of Lassa fever.

\section{References}

Abraham J, Corbett KD, Farzan M, Choe H, Harrison SC (2010) Structural basis for receptor recognition by New World hemorrhagic fever arenaviruses. Nat Struct Mol Biol 17:438-444. https://doi.org/10.1038/nsmb.1772

Ahmed R, Salmi A, Butler LD, Chiller JM, Oldstone MB (1984) Selection of genetic variants of lymphocytic choriomeningitis virus in spleens of persistently infected mice. Role in suppression of cytotoxic T lymphocyte response and viral persistence. J Exp Med 160:521-540

\footnotetext{
${ }^{2}$ Preparing for Lassa vaccine trials with targeted epidemiology studies, https://cepi.net/get_ involved/cfps/ (2019).
} 
Ajogbasile FV et al (2020) Real-time metagenomic analysis of undiagnosed fever cases unveils a yellow fever outbreak in Edo State, Nigeria. Sci Rep 10:3180. https://doi.org/10.1038/s41598020-59880-w

Akhuemokhan OC et al (2017) Prevalence of lassa virus disease (LVD) in Nigerian children with fever or fever and convulsions in an endemic area. PLoS Negl Tropical Dis 11:e0005711. https://doi.org/10.1371/journal.pntd.0005711

Andersen KG et al (2015) Clinical sequencing uncovers origins and evolution of Lassa virus. Cell 162:738-750. https://doi.org/10.1016/j.cell.2015.07.020

Arnold RB, Gary GW (1977) A neutralization test survey for Lassa Fever activity in Lassa, Nigeria. Trans R Soc Trop Med Hyg 71:152-154

Auperin DD et al (1988) Construction of a recombinant vaccinia virus expressing the Lassa virus glycoprotein gene and protection of guinea pigs from a lethal Lassa virus infection. Virus Res 9:233-248

Barber GN, Clegg JC, Lloyd G (1990) Expression of the Lassa virus nucleocapsid protein in insect cells infected with a recombinant baculovirus: application to diagnostic assays for Lassa virus infection. J Gen Virol 71(Pt 1):19-28. https://doi.org/10.1099/0022-1317-71-1-19

Bausch DG et al (2000) Diagnosis and clinical virology of Lassa fever as evaluated by enzyme-linked immunosorbent assay, indirect fluorescent-antibody test, and virus isolation. J Clin Microbiol 38:2670-2677

Bausch DG et al (2001) Lassa fever in Guinea: I. Epidemiology of human disease and clinical observations. Vector Borne Zoonotic Dis 1:269-281. https://doi.org/10.1089/ 15303660160025903

Bausch DG et al (2014) A tribute to Sheik Humarr Khan and all the healthcare workers in West Africa who have sacrificed in the fight against Ebola virus disease: Mae we hush. Antiviral Res 111C:33-35. https://doi.org/10.1016/j.antiviral.2014.09.001

Bernasconi $\mathrm{V}$ et al (2020) Developing vaccines against epidemic-prone emerging infectious diseases. Bundesgesundheitsblatt, Gesundheitsforschung, Gesundheitsschutz 63:65-73. https:// doi.org/10.1007/s00103-019-03061-2

Boisen ML et al (2016) Field validation of the ReEBOV antigen rapid test for point-of-care diagnosis of Ebola virus infection. J Infect Dis. https://doi.org/10.1093/infdis/jiw261

Boisen ML et al (2018) Field validation of recombinant antigen immunoassays for diagnosis of Lassa fever. Sci Rep 8:5939. https://doi.org/10.1038/s41598-018-24246-w

Bond N, Schieffelin JS, Moses LM, Bennett AJ, Bausch DG (2013) A historical look at the first reported cases of Lassa fever: IgG antibodies 40 years after acute infection. Am J Trop Med Hyg 88:241-244. https://doi.org/10.4269/ajtmh.2012.12-0466

Bowen MD et al (2000) Genetic diversity among Lassa virus strains. J Virol 74:6992-7004. https://doi.org/10.1128/jvi.74.15.6992-7004.2000

Branco LM et al (2008) Bacterial-based systems for expression and purification of recombinant Lassa virus proteins of immunological relevance. Virol J 5:74. https://doi.org/10.1186/1743$422 x-5-74$

Buchmeier MJ, Lewicki HA, Tomori O, Johnson KM (1980) Monoclonal antibodies to lymphocytic choriomeningitis virus react with pathogenic arenaviruses. Nature 288:486-487. https://doi.org/10.1038/288486a0

Buchmeier MJ, Lewicki HA, Tomori O, Oldstone MB (1981) Monoclonal antibodies to lymphocytic choriomeningitis and pichinde viruses: generation, characterization, and cross-reactivity with other arenaviruses. Virology 113:73-85. https://doi.org/10.1016/00426822(81)90137-9

Buckley SM, Casals J (1970) Lassa fever, a new virus disease of man from West Africa. 3. Isolation and characterization of the virus. Am J Trop Med Hyg 19:680-691

Buckley SM, Casals J, Downs WG (1970) Isolation and antigenic characterization of Lassa virus. Nature 227:174

Burki T (2017) CEPI: preparing for the worst. The Lancet. Infect Dis 17:265-266. https://doi.org/ 10.1016/s1473-3099(17)30062-2 
Campbell G (2002) Blood diamond: tracing the deadly path of the world's most precious stones. Westview Press

Cao W et al (1998) Identification of alpha-dystroglycan as a receptor for lymphocytic choriomeningitis virus and Lassa fever virus. Science 282:2079-2081. https://doi.org/10. $1126 /$ science. 282.5396 .2079

Carey DE et al (1972) Lassa fever. Epidemiological aspects of the 1970 epidemic, Jos, Nigeria. Trans R Soc Trop Med Hyg 66:402-408

Cashman KA et al (2017a) A DNA vaccine delivered by dermal electroporation fully protects cynomolgus macaques against Lassa fever. Human Vaccines Immunotherapeutics 13:29022911. https://doi.org/10.1080/21645515.2017.1356500

Cashman KA et al (2017b) DNA vaccines elicit durable protective immunity against individual or simultaneous infections with Lassa and Ebola viruses in guinea pigs. Hum Vaccines Immunotherapeutics 13:3010-3019. https://doi.org/10.1080/21645515.2017.1382780

Cashman KA. et al (2018) Immune-mediated systemic vasculitis as the proposed cause of sudden-onset sensorineural hearing loss following Lassa virus exposure in cynomolgus macaques. mBio 9. https://doi.org/10.1128/mbio.01896-18

Chu M (2018). In: Barton HA, Whitaker RJ (eds). Ch. 31 Amer Soc Microbiol

Clegg JC, Lloyd G (1983) Structural and cell-associated proteins of Lassa virus. J Gen Virol 64:1127-1136. https://doi.org/10.1099/0022-1317-64-5-1127

Clegg JC, Lloyd G (1987) Vaccinia recombinant expressing Lassa-virus internal nucleocapsid protein protects guineapigs against Lassa fever. Lancet 2:186-188. https://doi.org/10.1016/ s0140-6736(87)90767-7

Clegg JC, Barber GN, Chamberlain JF, Oram JD (1986) Expression of Lassa virus nucleocapsid gene fragments in bacteria. Med Microbiol Immunol 175:93-95

Cross RW et al (2016a) Analytical validation of the ReEBOV antigen rapid test for point-of-care diagnosis of Ebola virus infection. J Infect Dis. https://doi.org/10.1093/infdis/jiw293

Cross RW et al (2016b) Treatment of Lassa virus infection in outbred guinea pigs with first-in-class human monoclonal antibodies. Antiviral Res 133:218-222. https://doi.org/10. 1016/j.antiviral.2016.08.012

Cross RW et al (2019) Antibody therapy for Lassa fever. Curr Opin Virol 37:97-104. https://doi. org/10.1016/j.coviro.2019.07.003

Cummins D (1992) Rats, fever and sudden deafness in Sierra Leone. Trop Doct 22:83-84

Cummins D et al (1989) A plasma inhibitor of platelet aggregation in patients with Lassa fever. Br J Haematol 72:543-548

Cummins D et al (1990) Acute sensorineural deafness in Lassa fever. JAMA 264:2093-2096

Demby AH et al (2001) Lassa fever in Guinea: II. Distribution and prevalence of Lassa virus infection in small mammals. Vector Borne Zoonotic Dis 1:283-297. https://doi.org/10.1089/ 15303660160025912

Eberhardt KA et al (2019) Ribavirin for the treatment of lassa fever: a systematic review and meta-analysis. Int J Infect Dis: IJID: Official Publ Int Soci Infect Dis. https://doi.org/10.1016/j. ijid.2019.07.015

ECDC (2016) Lassa fever in Nigeria, Benin, Togo, Germany and USA. Eur Centre Dis Prev Control (23 Mar 2016)

Ehichioya DU et al (2011) Current molecular epidemiology of Lassa virus in Nigeria. J Clin Microbiol 49:1157-1161. https://doi.org/10.1128/jcm.01891-10

Ehichioya DU et al (2019) Phylogeography of Lassa virus in Nigeria. J Virol. https://doi.org/10. 1128/jvi.00929-19

Eichler R, Lenz O, Strecker T, Garten W (2003) Signal peptide of Lassa virus glycoprotein GP-C exhibits an unusual length. FEBS Lett 538:203-206. https://doi.org/10.1016/s0014-5793(03) 00160-1

Enria DA, Barrera Oro JG (2002) Junin virus vaccines. Curr Top Microbiol Immunol 263:239261

Enria DA, Maiztegui JI (1994) Antiviral treatment of Argentine hemorrhagic fever. Antiviral Res 23:23-31 
Enria DA, Briggiler AM, Sanchez Z (2008) Treatment of Argentine hemorrhagic fever. Antiviral Res 78:132-139. https://doi.org/10.1016/j.antiviral.2007.10.010

Enria DA, Ambrosio AM, Briggiler AM, Feuillade MR, Crivelli E (2010) [Candid\#1 vaccine against Argentine hemorrhagic fever produced in Argentina. Immunogenicity and safety]. Medicina 70:215-222

Fabiyi A, Tomori O (1975) Use of the complement fixation (CF) test in Lassa fever surveillance. Evidence for persistent CF antibodies. Bull World Health Organ 52, 605-608 (1975)

Fabiyi A, Tomori O, Pinneo P (1979) Lassa fever antibodies in hospital personnel in the Plateau State of Nigeria. Niger Med J 9:23-25

Fichet-Calvet E et al (2007) Fluctuation of abundance and Lassa virus prevalence in Mastomys natalensis in Guinea, West Africa. Vector Borne Zoonotic Dis 7:119-128. https://doi.org/10. 1089/vbz.2006.0520

Fichet-Calvet E, Lecompte E, Koivogui L, Daffis S, ter Meulen J (2008) Reproductive characteristics of Mastomys natalensis and Lassa virus prevalence in Guinea, West Africa. Vector Borne Zoonotic Dis 8:41-48. https://doi.org/10.1089/vbz.2007.0118

Fisher-Hoch SP et al (1985) Safe intensive-care management of a severe case of Lassa fever with simple barrier nursing techniques. Lancet 2:1227-1229

Fisher-Hoch SP et al (1987) Physiological and immunologic disturbances associated with shock in a primate model of Lassa fever. J Infect Dis 155:465-474. https://doi.org/10.1093/infdis/155.3. 465

Fisher-Hoch SP et al (1989) Protection of rhesus monkeys from fatal Lassa fever by vaccination with a recombinant vaccinia virus containing the Lassa virus glycoprotein gene. Proc Natl Acad Sci U S A 86:317-321. https://doi.org/10.1073/pnas.86.1.317

Fisher-Hoch SP et al (1995) Review of cases of nosocomial Lassa fever in Nigeria: the high price of poor medical practice. BMJ 311:857-859

Frame JD, Baldwin JM, Jr, Gocke DJ, Troup JM (1970) Lassa fever, a new virus disease of man from West Africa. I. Clinical description and pathological findings. Am J Trop Med Hyg 19:670-676

Frame JD, Casals J, Dennis EA (1979) Lassa virus antibodies in hospital personnel in western Liberia. Trans R Soc Trop Med Hyg 73:219-224. https://doi.org/10.1016/0035-9203(79) 90218-9

Frame JD, Verbrugge GP, Gill RG, Pinneo L (1984) The use of Lassa fever convalescent plasma in Nigeria. Trans R Soc Trop Med Hyg 78:319-324

Fraser DW, Campbell CC, Monath TP, Goff PA, Gregg MB (1974) Lassa fever in the Eastern Province of Sierra Leone, 1970-1972. I. Epidemiologic studies. Am J Trop Med Hyg 23, 1131-1139. https://doi.org/10.4269/ajtmh.1974.23.1131

Gallaher WR, DiSimone C, Buchmeier MJ (2001) The viral transmembrane superfamily: possible divergence of Arenavirus and Filovirus glycoproteins from a common RNA virus ancestor. BMC Microbiol 1:1

Garry CE, Garry RF (2019) Proteomics computational analyses suggest that the antennavirus glycoprotein complex includes a class I viral fusion protein (alpha-penetrene) with an Internal zinc-binding domain and a stable signal peptide. Viruses 11. https://doi.org/10.3390/ v11080750

Gire SK et al (2014) Genomic surveillance elucidates Ebola virus origin and transmission during the 2014 outbreak. Science 345:1369-1372. https://doi.org/10.1126/science.1259657

Goba A et al (2016) An outbreak of ebola virus disease in the lassa fever zone. J Infect Dis 214: S110-s121. https://doi.org/10.1093/infdis/jiw239

Gouglas D, Christodoulou M, Plotkin SA, Hatchett R (2019) CEPI: driving progress towards epidemic preparedness and response. Epidemiol Rev. https://doi.org/10.1093/epirev/mxz012

Hartnett JN et al (2015) Current and emerging strategies for the diagnosis, prevention and treatment of Lassa fever. Future Virol 10:559-584

Hastie KM, Saphire EO (2018) Lassa virus glycoprotein: stopping a moving target. Curr Opin Virol 31:52-58. https://doi.org/10.1016/j.coviro.2018.05.002 
Hastie KM et al (2011a) Crystal structure of the Lassa virus nucleoprotein-RNA complex reveals a gating mechanism for RNA binding. Proc Natl Acad Sci U S A 108:19365-19370. https://doi. org/10.1073/pnas.1108515108

Hastie KM, Kimberlin CR, Zandonatti MA, MacRae IJ, Saphire EO (2011b) Structure of the Lassa virus nucleoprotein reveals a dsRNA-specific 3 ' to 5 ' exonuclease activity essential for immune suppression. Proc Natl Acad Sci U S A 108:2396-2401. https://doi.org/10.1073/pnas. 1016404108

Hastie KM, Bale S, Kimberlin CR, Saphire EO (2012a) Hiding the evidence: two strategies for innate immune evasion by hemorrhagic fever viruses. Curr Opin Virol 2:151-156. https://doi. org/10.1016/j.coviro.2012.01.003

Hastie KM, King LB, Zandonatti MA, Saphire EO (2012b) Structural basis for the dsRNA specificity of the Lassa virus NP exonuclease. PLoS ONE 7:e44211. https://doi.org/10.1371/ journal.pone.0044211

Hastie KM et al (2017) Structural basis for antibody-mediated neutralization of Lassa virus. Science 356:923-928. https://doi.org/10.1126/science.aam7260

Hastie KM et al (2019) Convergent structures illuminate features for germline antibody binding and pan-lassa virus neutralization. Cell 178:1004-1015.e1014. https://doi.org/10.1016/j.cell. 2019.07.020

Henderson BE, Gary GW, Jr, Kissling RE, Frame JD, Carey DE (1972) Lassa fever. Virological and serological studies. Trans R Soc Trop Med Hyg 66:409-416

Jahrling PB et al (2014) The NIAID integrated research facility at Frederick, Maryland: a unique international resource to facilitate medical countermeasure development for BSL-4 pathogens. Pathog Dis 71:213-219. https://doi.org/10.1111/2049-632x.12171

Jiang J et al (2019) Immunogenicity of a protective intradermal DNA vaccine against Lassa virus in cynomolgus macaques. Human Vaccines \& Immunotherapeutics 15:2066-2074. https://doi. org/10.1080/21645515.2019.1616499

Johnson KM, Monath TP (1990) Imported Lassa fever-reexamining the algorithms. N Engl J Med 323:1139-1141

Johnson KM et al (1987) Clinical virology of Lassa fever in hospitalized patients. J Infect Dis 155:456-464. https://doi.org/10.1093/infdis/155.3.456

Kafetzopoulou LE et al (2019) Metagenomic sequencing at the epicenter of the Nigeria 2018 Lassa fever outbreak. Science 363:74-77. https://doi.org/10.1126/science.aau9343

Keenlyside RA et al (1983) Case-control study of Mastomys natalensis and humans in Lassa virus-infected households in Sierra Leone. Am J Trop Med Hyg 32:829-837

Kerneis S et al (2009) Prevalence and risk factors of Lassa seropositivity in inhabitants of the forest region of Guinea: a cross-sectional study. PLoS Negl Tropical Dis 3:e548. https://doi. org/10.1371/journal.pntd.0000548

Khan SH et al (2008) New opportunities for field research on the pathogenesis and treatment of Lassa fever. Antiviral Res 78:103-115. https://doi.org/10.1016/j.antiviral.2007.11.003

Kiley MP, Lange JV, Johnson KM (1979) Protection of rhesus monkeys from Lassa virus by immunisation with closely related Arenavirus. Lancet 2:738. https://doi.org/10.1016/s01406736(79)90659-7

Klavinskis LS, Oldstone MB (1989) Lymphocytic choriomeningitis virus selectively alters differentiated but not housekeeping functions: block in expression of growth hormone gene is at the level of transcriptional initiation. Virology 168:232-235. https://doi.org/10.1016/00426822(89)90262-6

Kunz S, Sevilla N, McGavern DB, Campbell KP, Oldstone MB (2001) Molecular analysis of the interaction of LCMV with its cellular receptor [alpha]-dystroglycan. J Cell Biol 155:301-310. https://doi.org/10.1083/jcb.200104103

Kunz S, Campbell KP, Oldstone MB (2003) Alpha-dystroglycan can mediate arenavirus infection in the absence of beta-dystroglycan. Virology 316:213-220. https://doi.org/10.1016/j.virol. 2003.07.002

Kunz S, Calder L, Oldstone MB (2004a) Electron microscopy of an alpha-dystroglycan fragment containing receptor sites for lymphocytic choriomeningitis virus and laminin, and use of the 
receptoid body as a reagent to neutralize virus. Virology 325:207-215. https://doi.org/10.1016/ j.virol.2004.04.044

Kunz S, Sevilla N, Rojek JM, Oldstone MB (2004b) Use of alternative receptors different than alpha-dystroglycan by selected isolates of lymphocytic choriomeningitis virus. Virology 325:432-445. https://doi.org/10.1016/j.virol.2004.05.009

Kunz S, Rojek JM, Perez M, Spiropoulou CF, Oldstone MB (2005) Characterization of the interaction of lassa fever virus with its cellular receptor alpha-dystroglycan. J Virol 79:59795987. https://doi.org/10.1128/jvi.79.10.5979-5987.2005

Lange JV et al (1985) Kinetic study of platelets and fibrinogen in Lassa virus-infected monkeys and early pathologic events in Mopeia virus-infected monkeys. Am J Trop Med Hyg 34:9991007

Lecompte E et al (2006) Mastomys natalensis and Lassa fever, West Africa. Emerg Infect Dis 12:1971-1974. https://doi.org/10.3201/eid1212.060812

Lee KJ, Novella IS, Teng MN, Oldstone MB, de La Torre JC (2000) NP and L proteins of lymphocytic choriomeningitis virus (LCMV) are sufficient for efficient transcription and replication of LCMV genomic RNA analogs. J Virol 74:3470-3477. https://doi.org/10.1128/ jvi.74.8.3470-3477.2000

Leifer E, Gocke DJ, Bourne H (1970) Lassa fever, a new virus disease of man from West Africa. II. Report of a laboratory-acquired infection treated with plasma from a person recently recovered from the disease. Am J Trop Med Hyg 19:677-679

Lloyd G, Barber GN, Clegg JC, Kelly P (1989) Identification of Lassa fever virus infection with recombinant nucleocapsid protein antigen. Lancet 2:1222. https://doi.org/10.1016/s0140-6736 (89)91833-3

Lukashevich IS (1985) Lassa virus lethality for inbred mice. Ann Soc Belg Med Trop 65:207-209

Lukashevich IS, Vasiuchkov AD, Mar'iankova RF, Votiakov VI (1982) [Factors affecting plaque formation by Lassa virus in Vero cells]. Vopr Virusol, 57-61

Lukashevich IS, Maryankova RF, Fidarov FM (1983) Reproduction of Lassa virus in different cell cultures. Acta Virol 27:282-285

Lukashevich LS, Clegg JC, Sidibe K (1993) Lassa virus activity in Guinea: distribution of human antiviral antibody defined using enzyme-linked immunosorbent assay with recombinant antigen. J Med Virol 40:210-217

Lukashevich IS et al (1997) The Lassa fever virus L gene: nucleotide sequence, comparison, and precipitation of a predicted $250 \mathrm{kDa}$ protein with monospecific antiserum. J Gen Virol 78(Pt 3):547-551. https://doi.org/10.1099/0022-1317-78-3-547

Lukashevich IS et al (1999) Lassa and Mopeia virus replication in human monocytes/macrophages and in endothelial cells: different effects on IL-8 and TNF-alpha gene expression. J Med Virol 59:552-560

Lukashevich IS et al (2008) Safety, immunogenicity, and efficacy of the ML29 reassortant vaccine for Lassa fever in small non-human primates. Vaccine 26:5246-5254. https://doi.org/10.1016/ j.vaccine.2008.07.057

Lunkenheimer K, Hufert FT, Schmitz H (1990) Detection of Lassa virus RNA in specimens from patients with Lassa fever by using the polymerase chain reaction. J Clin Microbiol 28:26892692

Madu IG et al (2018) A potent Lassa virus antiviral targets an arenavirus virulence determinant. PLoS Pathog 14:e1007439. https://doi.org/10.1371/journal.ppat.1007439

Mahmutovic S et al (2015) Molecular basis for antibody-mediated neutralization of new world hemorrhagic fever mammarenaviruses. Cell Host Microbe 18:705-713. https://doi.org/10. 1016/j.chom.2015.11.005

Manning JT, Forrester N, Paessler S (2015) Lassa virus isolates from Mali and the Ivory Coast represent an emerging fifth lineage. Front Microbiol 6:1037. https://doi.org/10.3389/fmicb. 2015.01037

Matranga CB et al (2014) Enhanced methods for unbiased deep sequencing of Lassa and Ebola RNA viruses from clinical and biological samples. Genome Biol 15:519. https://doi.org/ 10.1186/preaccept-1698056557139770 
McCormick JB (1986) Clinical, epidemiologic, and therapeutic aspects of Lassa fever. Med Microbiol Immunol (Berl) 175:153-155

McCormick JB et al (1986) Lassa fever. Effective therapy with ribavirin. N Engl J Med 314:20-26

McCormick JB, Fisher-Hoch S (1996) Level 4 Virus Hunters of the CDC (379). Turner Publications

McCormick JB et al (1987a) A case-control study of the clinical diagnosis and course of Lassa fever. J Infect Dis 155:445-455

McCormick JB, Webb PA, Krebs JW, Johnson KM, Smith ES (1987b) A prospective study of the epidemiology and ecology of Lassa fever. J Infect Dis 155:437-444. https://doi.org/10.1093/ infdis/155.3.437

McCormick JB, Mitchell SW, Kiley MP, Ruo S, Fisher-Hoch SP (1992) Inactivated Lassa virus elicits a non protective immune response in rhesus monkeys. J Med Virol 37:1-7

Mehand MS, Al-Shorbaji F, Millett P, Murgue B (2018) The WHO R\&D Blueprint: 2018 review of emerging infectious diseases requiring urgent research and development efforts. Antiviral Res 159:63-67. https://doi.org/10.1016/j.antiviral.2018.09.009

Mire CE et al (2017) Human-monoclonal-antibody therapy protects nonhuman primates against advanced Lassa fever. Nat Med 23:1146-1149. https://doi.org/10.1038/nm.4396

Monath TP (2019) A short history of Lassa fever: the first 10-15 years after discovery. Curr Opin Virol 37:77-83. https://doi.org/10.1016/j.coviro.2019.06.005

Monath TP et al (1973) A hospital epidemic of Lassa fever in Zorzor, Liberia, March-April 1972. Am J Trop Med Hyg 22:773-779. https://doi.org/10.4269/ajtmh.1973.22.773

Monath TP, Maher M, Casals J, Kissling RE, Cacciapuoti A (1974a) Lassa fever in the Eastern Province of Sierra Leone, 1970-1972. II. Clinical observations and virological studies on selected hospital cases. Am J Trop Med Hyg 23:1140-1149. https://doi.org/10.4269/ajtmh. 1974.23.1140

Monath TP, Newhouse VF, Kemp GE, Setzer HW, Cacciapuoti A (1974b) Lassa virus isolation from Mastomys natalensis rodents during an epidemic in Sierra Leone. Science 185:263-265. https://doi.org/10.1126/science.185.4147.263

Morrison HG et al (1989) Protection of guinea pigs from Lassa fever by vaccinia virus recombinants expressing the nucleoprotein or the envelope glycoproteins of Lassa virus. Virology 171:179-188. https://doi.org/10.1016/0042-6822(89)90525-4

Okogbenin S et al (2019) Retrospective cohort study of lassa fever in pregnancy, Southern Nigeria. Emerg Infect Dis 25, https://doi.org/10.3201/eid2508.181299

Okokhere P et al (2018) Clinical and laboratory predictors of Lassa fever outcome in a dedicated treatment facility in Nigeria: a retrospective, observational cohort study. Lancet Infect Dis 18:684-695. https://doi.org/10.1016/s1473-3099(18)30121-x

Olayemi A et al (2016a) Arenavirus diversity and phylogeography of Mastomys natalensis rodents, Nigeria. Emerg Infect Dis 22:694-697. https://doi.org/10.3201/eid2204.150155

Olayemi A et al (2016b) New hosts of the Lassa virus. Sci Rep 6:25280. https://doi.org/10.1038/ srep25280

Oldstone MB, Dixon FJ (1970) Tissue injury in lymphocytic choriomeningitis viral infection: virus-induced immunologically specific release of a cytotoxic factor from immune lymphoid cells. Virology 42:805-813

Oldstone MB, Dixon FJ (1972) Disease accompanying in utero viral infection. The role of maternal antibody in tissue injury after transplacental infection with lymphocytic choriomeningitis virus. J Exp Med 135:827-838. https://doi.org/10.1084/jem.135.4.827

Oldstone MB, Dixon FJ, Mitchell GF, McDevitt HO (1973) Histocompatibility-linked genetic control of disease susceptibility. Murine lymphocytic choriomeningitis virus infection. J Exp Med 137:1201-1212. https://doi.org/10.1084/jem.137.5.1201

Oldstone MB, Buchmeier MJ, Doyle MV, Tishon A (1980) Virus-induced immune complex disease: specific anti-viral antibody and $\mathrm{Clq}$ binding material in the circulation during persistent lymphocytic choriomeningitis virus infection. J Immunol 124:831-838 
Oldstone MB et al (1985) Virus and immune responses: lymphocytic choriomeningitis virus as a prototype model of viral pathogenesis. Br Med Bull 41:70-74. https://doi.org/10.1093/ oxfordjournals.bmb.a072029

Oldstone MB et al (1990) Cytotoxic T lymphocytes do not control lymphocytic choriomeningitis virus infection of BB diabetes-prone rats. J Gen Virol 71(Pt 4):785-791. https://doi.org/10. 1099/0022-1317-71-4-785

Oloniniyi OK et al (2018) Genetic characterization of Lassa virus strains isolated from 2012 to 2016 in southeastern Nigeria. PLoS Negl Tropical Dis 12:e0006971. https://doi.org/10.1371/ journal.pntd.0006971

Omilabu SA et al (2005) Lassa fever, Nigeria, 2003 and 2004. Emerg Infect Dis 11:1642-1644. https://doi.org/10.3201/eid1110.041343

Peng R et al (2020) Structural insight into arenavirus replication machinery. Nature 579:615-619. https://doi.org/10.1038/s41586-020-2114-2

Petkevich AS, Sabynin VM, Lukashevich IS, Galegov GA, Votiakov VI (1981) [Effect of ribovirin (virazole) on arenavirus reproduction in cell cultures]. Vopr Virusol 244-245

Pinneo L, Pinneo R (1971) Mystery virus from Lassa. Am J Nurs 71:1352-1355

Price ME, Fisher-Hoch SP, Craven RB, McCormick JB (1988) A prospective study of maternal and fetal outcome in acute Lassa fever infection during pregnancy. BMJ 297:584-587

Riviere Y, Ahmed R, Southern PJ, Buchmeier MJ, Oldstone MB (1985) Genetic mapping of lymphocytic choriomeningitis virus pathogenicity: virulence in guinea pigs is associated with the L RNA segment. J Virol 55:704-709

Riviere Y, Southern PJ, Ahmed R, Oldstone MB (1986) Biology of cloned cytotoxic T lymphocytes specific for lymphocytic choriomeningitis virus. V. Recognition is restricted to gene products encoded by the viral S RNA segment. J Immunol 136:304-307

Roberts PJ et al (1989) Plasma from patients with severe Lassa fever profoundly modulates f-met-leu-phe induced superoxide generation in neutrophils. Br J Haematol 73:152-157

Robinson JE et al (2016) Most neutralizing human monoclonal antibodies target novel epitopes requiring both Lassa virus glycoprotein subunits. Nat Commun 7:11544. https://doi.org/10. 1038/ncomms 11544

Rose JR (1956) A new clinical entity? Lancet 2:197

Rybak LP (1990) Deafness associated with Lassa fever. Jama 264:2119

Ryschon TW (2014) Ebola control measures and inadequate responses. Lancet 384:1181-1182. https://doi.org/10.1016/s0140-6736(14)61346-5

Sabeti PC et al (2006) Positive natural selection in the human lineage. Science 312:1614-1620. https://doi.org/10.1126/science.1124309

Sabeti PC et al (2007) Genome-wide detection and characterization of positive selection in human populations. Nature 449:913-918. https://doi.org/10.1038/nature06250

Safronetz D et al (2013) Geographic distribution and genetic characterization of Lassa virus in sub-Saharan Mali. PLoS Neg Trop Dis 7:e2582. https://doi.org/10.1371/journal.pntd.0002582

Salvato M, Borrow P, Shimomaye E, Oldstone MB (1991) Molecular basis of viral persistence: a single amino acid change in the glycoprotein of lymphocytic choriomeningitis virus is associated with suppression of the antiviral cytotoxic T-lymphocyte response and establishment of persistence. J Virol 65:1863-1869

Schieffelin JS et al (2014) Clinical illness and outcomes in patients with Ebola in sierra leone. N Engl J Med 371:2092-2100. https://doi.org/10.1056/NEJMoa1411680

Schmitz H, Emmerich P, ter Meulen J (1996) Imported tropical virus infections in Germany. Arch Virol Suppl 11:67-74

Schmitz H et al (2002) Monitoring of clinical and laboratory data in two cases of imported Lassa fever. Microbes Infect 4:43-50

Shaffer JG et al (2014) Lassa fever in post-conflict sierra leone. PLoS Negl Tropical Dis 8:e2748. https://doi.org/10.1371/journal.pntd.0002748

Siddle KJ et al (2018a) Genomic analysis of Lassa virus, 2018 Nigeria. NEJM accepted

Siddle KJ et al (2018b) Genomic analysis of lassa virus during an increase in cases in Nigeria in 2018. N Engl J Med 379:1745-1753. https://doi.org/10.1056/NEJMoa1804498 
Smelt SC et al (2001) Differences in affinity of binding of lymphocytic choriomeningitis virus strains to the cellular receptor alpha-dystroglycan correlate with viral tropism and disease kinetics. J Virol 75:448-457. https://doi.org/10.1128/jvi.75.1.448-457.2001

Smith EA, Fabiyi A, Kuteyi OE, Tomori O (1979) Epidemiological aspect of the 1976 Pankshin Lassa fever outbreak. Niger Med J 9:20-22

Southern PJ et al (1987) Molecular characterization of the genomic S RNA segment from lymphocytic choriomeningitis virus. Virology 157:145-155. https://doi.org/10.1016/00426822(87)90323-0

Speir RW, Wood O, Liebhaber H, Buckley SM (1970) Lassa fever, a new virus disease of man from West Africa. IV. Electron microscopy of Vero cell cultures infected with Lassa virus. Am J Trop Med Hyg 19:692-694. https://doi.org/10.4269/ajtmh.1970.19.692

Spiropoulou CF, Kunz S, Rollin PE, Campbell KP, Oldstone MB (2002) New World arenavirus clade $\mathrm{C}$, but not clade A and B viruses, utilizes alpha-dystroglycan as its major receptor. J Virol 76:5140-5146. https://doi.org/10.1128/jvi.76.10.5140-5146.2002

Stephen EL, Jahrling PB (1979) Experimental Lassa fever virus infection successfully treated with ribavirin. Lancet 1:268-269

Strecker $\mathrm{T}$ et al (2003) Lassa virus $\mathrm{Z}$ protein is a matrix protein and sufficient for the release of virus-like particles [corrected]. J Virol 77:10700-10705. https://doi.org/10.1128/jvi.77.19. 10700-10705.2003

Sullivan BM et al (2011) Point mutation in the glycoprotein of lymphocytic choriomeningitis virus is necessary for receptor binding, dendritic cell infection, and long-term persistence. Proc Natl Acad Sci U S A 108:2969-2974. https://doi.org/10.1073/pnas.1019304108

Sullivan BM et al (2020) High crossreactivity of human T cell responses between Lassa virus lineages. PLoS Pathog 16:e1008352. https://doi.org/10.1371/journal.ppat.1008352

Teng MN, Borrow P, Oldstone MB, de la Torre JC (1996) A single amino acid change in the glycoprotein of lymphocytic choriomeningitis virus is associated with the ability to cause growth hormone deficiency syndrome. J Virol 70:8438-8443

Tishon A, Southern PJ, Oldstone MB (1988) Virus-lymphocyte interactions. II. Expression of viral sequences during the course of persistent lymphocytic choriomeningitis virus infection and their localization to the L3T4 lymphocyte subset. J Immunol 140:1280-1284

Tishon A, Eddleston M, de la Torre JC, Oldstone MB (1993) Cytotoxic T lymphocytes cleanse viral gene products from individually infected neurons and lymphocytes in mice persistently infected with lymphocytic choriomeningitis virus. Virology 197:463-467. https://doi.org/10. 1006/viro.1993.1613

Tomori O, Fabiyi A (1979) Lassa fever virus: properties and characteristics. Niger Med J 9:17-19

Tomori O, Johnson KM, Kiley MP, Elliott LH (1987) Standardization of a plaque assay for Lassa virus. J Med Virol 22:77-89

Tomori O, Fabiyi A, Sorungbe A, Smith A, McCormick JB (1988) Viral hemorrhagic fever antibodies in Nigerian populations. Am J Trop Med Hyg 38:407-410. https://doi.org/10.4269/ ajtmh.1988.38.407

Tomori O et al (1999) Serologic survey among hospital and health center workers during the Ebola hemorrhagic fever outbreak in Kikwit, Democratic Republic of the Congo, 1995. J Infect Dis 179(Suppl 1):S98-101. https://doi.org/10.1086/514307

Trappier SG et al (1993) Evaluation of the polymerase chain reaction for diagnosis of Lassa virus infection. Am J Trop Med Hyg 49:214-221

Troup JM, White HA, Fom AL, Carey DE (1970) An outbreak of Lassa fever on the Jos plateau, Nigeria, in January-February 1970. A preliminary report. Am J Trop Med Hyg 19:695-696

Valsamakis V et al (1986) Dissecting the molecular anatomy of persistent infection with lymphocytic choriomeningitis virus. Med Microbiol Immunol 175:97-99

Vieth S, Torda AE, Asper M, Schmitz H, Gunther S (2004) Sequence analysis of L RNA of Lassa virus. Virology 318:153-168. https://doi.org/10.1016/j.virol.2003.09.009

Walker DH et al (1982a) Experimental infection of rhesus monkeys with Lassa virus and a closely related arenavirus, Mozambique virus. J Infect Dis 146:360-368 
Walker DH et al (1982b) Pathologic and virologic study of fatal Lassa fever in man. Am J Pathol 107:349-356

Watts GM (2013) Lily Lyman Pinneo. The Lancet 380:1552

Webb PA et al (1986) Lassa fever in children in Sierra Leone, West Africa. Trans R Soc Trop Med Hyg 80:577-582

Welsh RM, Oldstone MB (1977) Inhibition of immunologic injury of cultured cells infected with lymphocytic choriomeningitis virus: role of defective interfering virus in regulating viral antigenic expression. J Exp Med 145:1449-1468. https://doi.org/10.1084/jem.145.6.1449

Welsh RM, Lampert PW, Oldstone MB (1977) Prevention of virus-induced cerebellar diseases by defective-interfering lymphocytic choriomeningitis virus. J Infect Dis 136:391-399. https://doi. org/10.1093/infdis/136.3.391

White HA (1972) Lassa fever. A study of 23 hospital cases. Trans R Soc Trop Med Hyg 66:390 401

Whitmer SLM et al (2018) New Lineage of Lassa Virus, Togo, 2016. Emerg Infect Dis 24:599_ 602. https://doi.org/10.3201/eid2403.171905

Whitton JL, Southern PJ, Oldstone MB (1988) Analyses of the cytotoxic T lymphocyte responses to glycoprotein and nucleoprotein components of lymphocytic choriomeningitis virus. Virology 162:321-327. https://doi.org/10.1016/0042-6822(88)90471-0

WHO (2017) Lassa Fever-Benin, Togo and Burkina Faso. Disease outbreak news, 10 Mar 2017

Wiley MR et al (2019) Lassa virus circulating in Liberia: a retrospective genomic characterisation. The Lancet. Infect Dis. https://doi.org/10.1016/s1473-3099(19)30486-4

Wright P (2004) Aniru Conteh. Lancet 363:1831

Wulff H, Johnson KM (1979) Immunoglobulin M and G responses measured by immunofluorescence in patients with Lassa or Marburg virus infections. Bull World Health Organ 57:631-635

Yadouleton A et al (2019) Lassa virus in Pygmy Mice, Benin, West Africa, 2016-2017. Emerg Infect Dis 25 https://doi.org/10.3201/eid2510.180523

York J, Nunberg JH (2006) Role of the stable signal peptide of Junin arenavirus envelope glycoprotein in pH-dependent membrane fusion. J Virol 80:7775-7780. https://doi.org/10. 1128/jvi.00642-06

York J, Nunberg JH (2007) A novel zinc-binding domain is essential for formation of the functional Junin virus envelope glycoprotein complex. J Virol 81:13385-13391. https://doi. org/10.1128/jvi.01785-07

York J, Nunberg JH (2018) A cell-cell fusion assay to assess arenavirus envelope glycoprotein membrane-fusion activity. Methods Mol Biol 1604:157-167. https://doi.org/10.1007/978-14939-6981-4_10

York J, Romanowski V, Lu M, Nunberg JH (2004) The signal peptide of the Junin arenavirus envelope glycoprotein is myristoylated and forms an essential subunit of the mature G1-G2 complex. J Virol 78:10783-10792. https://doi.org/10.1128/jvi.78.19.10783-10792.2004

York J, Dai D, Amberg SM, Nunberg JH (2008) pH-induced activation of arenavirus membrane fusion is antagonized by small-molecule inhibitors. J Virol 82:10932-10939. https://doi.org/10. 1128/jvi.01140-08

York J et al (2010) An antibody directed against the fusion peptide of Junin virus envelope glycoprotein GPC inhibits pH-induced membrane fusion. J Virol 84:6119-6129. https://doi. org/10.1128/jvi.02700-09 